\title{
ANALISIS KESTABILAN PENYEBARAN PENYAKIT ANTRAKS PADA POPULASI HEWAN DENGAN PEMBERIAN VAKSINASI: STUDI KASUS UNTUK INFEKSI PADA POPULASI MANUSIA
}

\author{
Megawati ${ }^{1}$, R. Ratianingsih ${ }^{2}$, dan $\mathrm{Hajar}^{3}$ \\ 1,2,3Program Studi Matematika Jurusan Matematika FMIPA Universitas Tadulako \\ Jalan Soekarno-Hatta Km. 09 Tondo, Palu 94118, Indonesia. \\ 1Megawati.tahir38@gmail.com, 2ratianingsih@yahoo.com,3hajar.200490@yahoo.com
}

\begin{abstract}
Anthrax is an infectious disease that caused by the Bacillus anthracis bacteria. The disease attacks animals such as cows in acute and preacute stage. Anthrax is a zoonotic disease that can be transmitted to humans through three types of media that are skin, digestive and respiratory tracts. To overcome the high death risk, treatment and vaccination of the period $6-12$ months are conducted. The aims of this study is developing a mathematical model of anthrax spread in animal populations with vaccination treatment. The model is also consider human populations, such that the SIRSV model (susceptible, Infected, Recovered, susceptible and Vaccine) is used for animal population and SI model (susceptible, Infected) is used for human population. The stability of model is analyzed at the critical points by linearization method. The free-disease unstable critical point and the stable endemic critical point are derived. The simulation shous that the number of infected animal and infected human population is not significantly different and indicates that the vaccination treatment could overcome the spread of anthrax succesfully.

\section{Keywords $\quad$ : Anthrax, Critical Point Endemic, Critical Point Non Disease, linearization method, Mathematical} Models
\end{abstract}

\section{ABSTRAK}

Antraks merupakan penyakit menular yang disebabkan oleh bakteri Bacillus Anthracis. Penyakit tersebut dapat menyerang hewan mamalia seperti sapi, yang dapat ditemukan dalam bentuk akut dan perakut. Penyakit Antraks dikategorikan sebagai penyakit zoonosis sehingga dapat menular ke manusia melalui tiga cara yaitu melalui kulit, pencernaan dan pernafasan. Untuk mengatasi tingginya kematian yang menimbulkan kerugian pada ternak, dilakukan pengobatan dan vaksinasi setiap $6-12$ bulan. Penelitian ini bertujuan untuk membangun model matematika penyebaran penyakit Antraks pemberian vaksinasi populasi hewan. Model yang dibangun dengan melibatkan infeksi penyakit tersebut pada populasi manusia ini menggunakan model SIRSV (Susceptible, Infected, Recovered, Susceptible dan Vaccine) untuk populasi hewan dan model SI (Susceptible, Infected) untuk populasi manusia. Kestabilan model dianalisa disetiap titik kritis dengan menggunakan metode linearisasi. Dari model matematika yang dibangun diperoleh titik kritis bebas penyakit yang tidak stabil dan titik kritis endemik yang stabil. 
Dari simulasi model pada kedua titik kritis tersebut dapat disumpulkan bahwa dalam waktu yang sama perbedaan banyaknya anggota sub populasi hewan terinfeksi dan populasi manusia terinfeksi untuk kedua titik kritis tersebut tidak signifikan dan menunjukkan keberhasilan program vaksinasi dalam mengatasi endemisitas penyebaran penyakit antraks.

Kata Kunci $\quad$ : Antraks, Titik Kritis Endemik, Titik Kritis Bebas Penyakit, Metode Linearisasi, Model Matematika

\section{PENDAHULUAN}

Antraks adalah penyakit menular yang disebabkan oleh bakteri Bacillus Anthracis, yang bersifat fatal serta menyerang baik hewan maupun manusia (OIE, 1992 dalam Hardjoutomo dan Poerwadikarta, 1996). Penyakit ini merupakan salah satu penyakit yang sudah dikenal selama berabad-abad. Kuman antraks pertama kali di isolasi oleh Robert Koch pada tahun 1877. Kata antraks dapat diartikan dalam bahasa Yunani dan istilah dengan kata "arang" atau "batubara", dalam bahasa inggris "coal" dan dalam bahasa prancis di sebut "charbon". Kata ini digunakan karena kulit para korban akan berubah menjadi hitam (Widoyono, 2008 dalam H.S. Gigieh., 2012). Antraks ada dihampir semua negara Afrika dan Asia, beberapa negara di Eropa, beberapa negara bagian Amerika Serikat dan beberapa daerah di Australia (WHO, 1998; Todar, 2002 dalam Adji dan Natalia, 2006). Menurut Soemanagara (1958) dalam Hardjoutomo dan Poerwadikarta, 1996, sejak tahun 1885 antraks pada hewan di Indonesia telah lama dikenal dan telah dibuktikan keberadaannya secara laboratorik. Sehingga penyakit antraks sudah endemik dan kasus tersebut terjadi di setiap tahun di berbagai daerah di Indonesia.

Penyakit antraks dapat menyerang hewan domestik maupun liar, terutama hewan pada herbivora seperti sapi dan dapat pula menyerang manusia (OIE, 2000; Todar, 2002 dalam Adji dan Natalia, 2006). Hewan dapat tertular antraks melalui pakan (rumput) atau minum yang terkontaminasi spora. Penyakit tersebut merupakan zoonosis khususnya binatang pemakan rumput atau ternak seperti sapi. Oleh karena itu, manusia dapat terinfeksi penyakit ini apabila endospora masuk ke dalam tubuh melalui kulit yang lecet atau luka, pernafasan atau makanan yang terkontaminasi. Antraks pada manusia juga dibedakan menjadi tipe kulit, tipe pencernaan, tipe pernafasan dan tipe meningitis. Wilayah yang terserang antraks biasanya lebih bersifat terbatas. Daerah-daerah yang terserang antraks biasanya memiliki tanah yang bersifat alkalis dan kaya bahan-bahan organik (Subronto, 2003 dalam Yakin, 2010). Sumber utama infeksi kuman adalah tanah dan air. Faktor yang mempercepat penularan penyakit antraks adalah musim panas, kekurangan makanan dan keletihan (Astiti, 2010). Untuk mencegah dan mengurangi infeksi penyakit antraks pada hewan yang merugikan ekonomi. Dapat dilakukan pengobatan terhadap hewan terinfeksi antraks tahap awal dan vaksinansi terhadap hewan yang masih sehat atau yang telah sembuh dari antraks.

Berdasarkan penyebaran penyakit antraks pada populasi hewan akan dikaji melalui model epidemi SIR dan pada populasi manusia akan dikaji melalui model epidemi SI. Dalam model tersebut populasi hewan dibagi menjadi 4 kelompok yaitu kelompok individu yang retan (Susceptible), 
kelompok individu yang terinfksi (Infected), kelompok individu yang telah sembuh (Recovered). Pada populasi manusia dibagi menjadi 2 kelompok yaitu kelompok individu yang rentan (Susceptible) dan kelompok individu yang terinfeksi (Infected). Model yang dibangun akan diuji kestabilannya di titik kritis bebas penyakit dan endemik dari model tersebut dengan menggunakan matriks Jacobi yang di peroleh dengan metode Linearisasi.

\section{METODE PENELITIAN}

\subsection{Jenis Dan Sumber Data}

Secara umum jenis data yang digunakan adalah data kuantitatif yang meliputi nilai parameter-parameter yang tercakup dalam model matematika yang bersumber dari literatur yang ada, sedangkan sumber data yang digunakan dalam penelitian ini adalah data sekunder.

\subsection{Prosedur Penelitian}

Penelitian dilakukan sesuai prosedur dibawah ini :

1. Memulai penelitian.

2. Mengkaji literatur, membuat asumsi-asumsi, mendefinisikan parameter yang digunakan pada model penyakit antraks.

3. Membangun model matematika penyebaran penyakit antraks.

4. Menentukan titik-titik kritis model tersebut serta menganalisa sifat kestabilan titik-titik kritis dari model tersebut.

5. Membuat simulasi dan menyimpulkan hasil penelitian.

\section{HASIL DAN PEMBAHASAN}

\subsection{Membangun Model Matematika Penyebaran Penyakit Antarks}

Model penyebaran penyakit antraks dapat dibangun dari diagram alur penyebaran penyakit tersebut yang terdapat pada Gambar 1 .

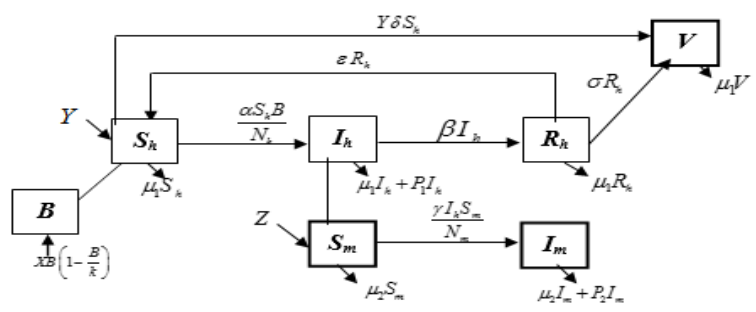

Gambar 1 : Diagram Alur Penyebaran Penyakit Antraks

Melalui diagram alur pada Gambar 1 penyebab infeksi Bacillus Anthracis $(B)$, populasi hewan rentan $\left(s_{h}\right)$, populasi hewan terinfeksi $\left(I_{h}\right)$, populasi hewan sembuh $\left(R_{h}\right)$, populasi 
hewan divaksin $(\mathrm{V})$, populasi manusia rentan $\left(s_{m}\right)$, dan populasi manusia terinfeksi $\left(I_{m}\right)$, dengan jumlah populasi hewan $N_{h}=S_{h}+I_{h}+R_{h}+V$ dan jumlah populasi manusia $N_{m}=S_{m}+I_{m}$ dibangun dalam suatu model berupa sistem persamaan diferensial tak linier sebagai berikut :

$$
\begin{aligned}
& \frac{d B}{d t}=X B\left(1-\frac{B}{k}\right) \\
& \frac{d S_{h}}{d t}=Y-\frac{\alpha S_{h} B}{N_{h}}+\varepsilon R_{h}-Y \delta S_{h}-\mu_{1} S_{h} \\
& \frac{d I_{h}}{d t}=\frac{\alpha S_{h} B}{N_{h}}-\beta I_{h}-\mu_{1} I_{h}-P_{1} I_{h} \\
& \frac{d R_{h}}{d t}=\beta I_{h}-\varepsilon R_{h}-\sigma R_{h}-\mu_{1} R_{h} \\
& \frac{d V}{d t}=Y \delta S_{h}+\sigma R_{h}-\mu_{1} V \\
& \frac{d S_{m}}{d t}=Z-\frac{\gamma I_{h} S_{m}}{N_{m}}-\mu_{2} S_{m} \\
& \frac{d I_{m}}{d t}=\frac{\gamma I_{h} S_{m}}{N_{m}}-\mu_{2} I_{m}-P_{2} I_{m}
\end{aligned}
$$

\subsection{Penentuan Titik Kritis}

Titik kritis penyebaran penyakit antarks dapat dibangun dari persamaan (1) - (7) dalam keadaan stagnan atau tidak dapat perubahan dalam populasi.

$$
\frac{d B}{d t}=0, \frac{d S_{h}}{d t}=0, \frac{d I_{h}}{d t}=0, \frac{d R_{h}}{d t}=0, \frac{d V}{d t}=0, \frac{d S_{m}}{d t}=0, \frac{d I_{m}}{d t}=0
$$

Sehingga dapat diperoleh dua titik kritis yakni titik kritis bebas penyakit yang diekspresikan sebagai $T_{0}=\left(0, \frac{Y}{Y \delta+\mu_{1}}, 0,0, \frac{Y^{2} \delta}{\mu_{1}\left(Y \delta+\mu_{1}\right)}, \frac{Z}{\mu_{2}}, 0\right)$ dan titik kritis endemik diekspresikan sebagai $T_{1}=\left(B, S_{h}, I_{h}, R_{h}, V, S_{m}, I_{m}\right)$ dimana :

$B=k$

$$
\begin{aligned}
& S_{h}=\frac{Y N_{h}\left(\beta+\mu_{1}+P_{1}\right)\left(\varepsilon+\sigma+\mu_{1}\right)}{\left(N_{h}\left(Y \delta+\mu_{1}\right)\left(\beta+\mu_{1}+P_{1}\right)\left(\varepsilon+\sigma+\mu_{1}\right)+k\left(\left(\beta+\mu_{1}+P_{1}\right) \mu_{1}\right.\right.} \\
& \left.\left.+\left(\mu_{1}+P_{1}\right) \varepsilon+\left(\beta+\mu_{1}+P_{1}\right) \sigma\right) \alpha\right) \\
& I_{h}=\frac{Y \alpha k\left(\varepsilon+\sigma+\mu_{1}\right)}{\left(N_{h}\left(Y \delta+\mu_{1}\right)\left(\beta+\mu_{1}+P_{1}\right)\left(\varepsilon+\sigma+\mu_{1}\right)+k\left(\left(\beta+\mu_{1}+P_{1}\right) \mu_{1}\right.\right.} \\
& \left.\left.+\left(\mu_{1}+P_{1}\right) \varepsilon+\left(\beta+\mu_{1}+P_{1}\right) \sigma\right) \alpha\right)
\end{aligned}
$$




$$
\begin{aligned}
& R_{h}=\frac{Y \beta \alpha k}{\left(N_{h}\left(Y \delta+\mu_{1}\right)\left(\beta+\mu_{1}+P_{1}\right)\left(\varepsilon+\sigma+\mu_{1}\right)+k\left(\left(\beta+\mu_{1}+P_{1}\right) \mu_{1}\right.\right.} \\
& \left.\left.+\left(\mu_{1}+P_{1}\right) \varepsilon+\left(\beta+\mu_{1}+P_{1}\right) \sigma\right) \alpha\right) \\
& V=\frac{Y\left(Y \delta \varepsilon N_{h}\left(\beta+\mu_{1}+P_{1}\right)\left(\varepsilon+\sigma+\mu_{1}\right)+k \alpha \sigma \beta\right)}{\mu_{1}\left(\begin{array}{l}
N_{h}\left(Y \delta+\mu_{1}\right)\left(\beta+\mu_{1}+P_{1}\right)\left(\varepsilon+\sigma+\mu_{1}\right)+k\left(\left(\beta+\mu_{1}+P_{1}\right) \mu_{1}\right. \\
\left.+\left(\mu_{1}+P_{1}\right) \varepsilon+\left(\beta+\mu_{1}+P_{1}\right) \sigma\right) \alpha
\end{array}\right)} \\
& S_{m}=\frac{Z\left(\begin{array}{l}
N_{m} N_{h}\left(Y \delta+\mu_{1}\right)\left(\beta+\mu_{1}+P_{1}\right)\left(\varepsilon+\sigma+\mu_{1}\right)+k\left(\left(\beta+\mu_{1}+P_{1}\right) \mu_{1}\right. \\
\left.+\left(\mu_{1}+P_{1}\right) \varepsilon+\left(\beta+\mu_{1}+P_{1}\right) \sigma\right) \alpha N_{m}
\end{array}\right)}{N_{m} N_{h}\left(Y \delta+\mu_{1}\right)\left(\beta+\mu_{1}+P_{1}\right)\left(\varepsilon+\sigma+\mu_{1}\right) \mu_{2}+k\left(\mu _ { 2 } \left(\left(\beta+\mu_{1}+P_{1}\right) \mu_{1}\right.\right.} \\
& \left.\left.+\left(\mu_{1}+P_{1}\right) \varepsilon+\left(\beta+\mu_{1}+P_{1}\right) \sigma\right) N_{m}+\gamma Y\left(\varepsilon+\sigma+\mu_{1}\right)\right) \alpha \\
& I_{m}=\frac{\gamma Y \alpha k\left(\varepsilon+\sigma+\mu_{1}\right) Z}{\left(\mu_{2}+P_{2}\right)\left(\begin{array}{l}
N_{m} N_{h}\left(Y \delta+\mu_{1}\right)\left(\beta+\mu_{1}+P_{1}\right)\left(\varepsilon+\sigma+\mu_{1}\right) \mu_{2} \\
+k\left(\mu _ { 2 } \left(\left(\beta+\mu_{1}+P_{1}\right) \mu_{1}+\left(\mu_{1}+P_{1}\right) \varepsilon\right.\right. \\
\left.\left.+\left(\beta+\mu_{1}+P_{1}\right) \sigma\right) N_{m}+\gamma Y\left(\varepsilon+\sigma+\mu_{1}\right)\right) \alpha
\end{array}\right)}
\end{aligned}
$$

\subsection{Kestabilan Titik Kritis}

Untuk mengkaji kestabilan titik kritis bebas penyakit terlebih dahulu dilakukan transformasi terhadap variabel $S_{h}, V$, dan $S_{m}$. Matriks Jacobi dari sistem persamaan dalam sistem koordinat baru selanjutnya yang dievaluasi di titik $(0,0,0,0,0,0,0)$ sehingga menghasilkan nilai-nilai eigen sebagai berikut :

$$
\begin{aligned}
& \lambda_{1}=X \\
& \lambda_{2}=-X \delta-\mu_{1} \ldots \\
& \lambda_{3}=-\beta-\mu_{1}-P_{1} \\
& \lambda_{4}=-\varepsilon-\sigma-\mu_{1} \\
& \lambda_{5}=-\mu_{1} \\
& \lambda_{6}=-\mu_{2} \ldots \ldots \ldots \ldots \\
& \lambda_{7}=-\mu_{2}-P_{2} \ldots \ldots
\end{aligned}
$$

Mengingat nilai $\lambda_{1}$ positif dan $\lambda_{2}, \lambda_{3}, \lambda_{4}, \lambda_{5}, \lambda_{6}, \lambda_{7}$ negatif, sistem tersebut tidak stabil dititik kritis $T_{0}$. Kestabilan titik kritis endemik terlebih dahulu dianalisa dengan melakukan transformasi terhadap variabel $\left(B, S_{h}, I_{h}, R_{h}, V, S_{m}, I_{m}\right)$. Sehingga Matriks Jacobi sistem di titik kritis baru $(0,0,0,0,0,0,0)$ memberikan persamaan karakteristik sebagai berikut :

$$
a_{0} \lambda^{7}+a_{1} \lambda^{6}+a_{2} \lambda^{5}+a_{3} \lambda^{4}+a_{4} \lambda^{3}+a_{5} \lambda^{2}+a_{6} \lambda+a_{7}=0
$$

Dengan

$$
a_{0}=-1, a_{1}=-\frac{a}{b}, a_{2}=-\frac{c}{b}, a_{3}=-\frac{d}{b}, a_{4}=-\frac{e}{b}, a_{5}=-\frac{f}{b}, a_{6}=-\frac{g}{b}, a_{7}=-\frac{h}{m}
$$




\section{Dimana}

$$
\begin{aligned}
& a=A B E+G B+C E>0, b=B E>0, c=H B E+A B G+A E C+G C+E J>0, \\
& d=K E B+H G B+A E C+A G C+A E J+G J+E L>0, e=K B G+K E C+H G C+H E J+A G J+A E L+G L>0 \\
& f=K G C+K E J+H G J+H E L+A G L>0, g=K G J+K E L+H G L>0, h=K G>0, m=M>0 \\
& \text { dengan } \\
& A=X+P_{2}+\mu_{1}+\mu_{2} \\
& B=N_{h} \\
& E=N_{h} N_{m}\left(Y \delta+\mu_{1}\right)\left(\beta+\mu_{1}+P_{1}\right)\left(\varepsilon+\sigma+\mu_{1}\right)+k\left(\left(\beta+\mu_{1}+P_{1}\right) \mu_{1}+\left(\mu_{1}+P_{1}\right) \varepsilon+\left(\beta+\mu_{1}+P_{1}\right) \sigma\right) \alpha N_{m} \\
& G=N_{h} N_{m}\left(Y \delta+\mu_{1}\right)\left(\beta+\mu_{1}+P_{1}\right)\left(\varepsilon+\sigma+\mu_{1}\right) \mu_{2}+k\left(\mu_{2}\left(\left(\beta+\mu_{1}+P_{1}\right) \mu_{1}+\left(\mu_{1}+P_{1}\right) \varepsilon+\left(\beta+\mu_{1}+P_{1}\right) \sigma\right)_{m}+\gamma Y\left(\varepsilon+\sigma+\mu_{1}\right)\right) \alpha \\
& C=\left(\left(\beta+3 \mu_{1}+P_{1}+\varepsilon+\sigma+Y \delta\right) N_{h}+\alpha k\right) \\
& H=X \mu_{1}+\left(X+\mu_{1}\right)\left(\mu_{1}+P_{2}\right) \\
& J=\left(\beta+\mu_{1}+P_{1}\right)\left(\varepsilon+\sigma+\mu_{1}\right) N_{h}+\left(\beta+2 \mu_{1}+P_{1}+\varepsilon+\sigma\right)\left(\alpha k+N_{h} \mu_{1}\right) \\
& K=X\left(\mu_{2}+P_{2}\right) \mu_{1} \\
& L=N_{h}\left(Y \delta+\mu_{1}\right)\left(\beta+\mu_{1}+P_{1}\right)\left(\varepsilon+\sigma+\mu_{1}\right)+k\left(\left(\beta+\mu_{1}+P_{1}\right) \mu_{1}+\left(\mu_{1}+P_{1}\right) \varepsilon+\left(\beta+\mu_{1}+P_{1}\right) \sigma\right) \alpha \\
& M=N_{h} N_{m}
\end{aligned}
$$

Persamaan karakteristik pada persamaan (23) memiliki koefisien $a_{0}, a_{1}, a_{2}, a_{3}, a_{4}, a_{5}, a_{6}$ dan $a_{7}$ bernilai negatif. Koefisien-koefisien tersebut ditabelkan mengikuti karakteristik Routh Hurwitz sebagai berikut :

Tabel 1 : Tabel Routh Hurwitz

\begin{tabular}{|c|c|c|c|c|}
\hline$\lambda^{7}$ & $a_{0}$ & $a_{2}$ & $a_{4}$ & $a_{6}$ \\
\hline$\lambda^{6}$ & $a_{1}$ & $a_{3}$ & $a_{5}$ & $a_{7}$ \\
\hline$\lambda^{5}$ & $b_{1}$ & $b_{2}$ & $b_{3}$ & 0 \\
\hline$\lambda^{4}$ & $c_{1}$ & $c_{2}$ & $c_{3}$ & 0 \\
\hline$\lambda^{3}$ & $d_{1}$ & $d_{2}$ & 0 & 0 \\
\hline$\lambda^{2}$ & $e_{1}$ & $e_{2}$ & 0 & 0 \\
\hline$\lambda^{1}$ & $f_{1}$ & 0 & 0 & 0 \\
\hline$\lambda^{0}$ & $g_{1}$ & 0 & 0 & 0 \\
\hline
\end{tabular}




\section{Dengan}

$$
\begin{aligned}
& b_{1}=-\frac{a c-d b}{a b}, b_{2}=-\frac{a e-f b}{a b}, b_{3}=-\frac{a g m-h b^{2}}{a b m}, c_{1}=-\frac{(a c d+a f b)-\left(d^{2} b+a^{2} e\right)}{b(a c-d b)}, \\
& c_{2}=-\frac{\left(a c f m+a b^{2} h\right)-\left(a^{2} g m+d b f m\right)}{b m(a c-d b)}, c_{3}=-\frac{h}{m}, \\
& d_{1}=-\frac{\left(a c d e m+2 a f b e m+c d b f m+a^{2} c g m+b^{3} d h\right)-\left(d^{2} b e m+a^{2} e^{2} m+b^{2} f^{2} m+a c^{2} f m+a c b h+a d b g m\right)}{b m\left((a c d+a f b)-\left(d^{2} b+a^{2} e\right)\right)}, \\
& d_{2}=-\frac{\left(a c d g m+a f b g m+a b^{2} e h+c d b^{2} h\right)-\left(d^{2} b g m+a^{2} e g m+b^{3} f h+a c^{2} b h\right)}{b m\left((a c d+a f b)-\left(d^{2} b+a^{2} e\right)\right)}, \\
& \left(\begin{array}{l}
g^{2} a^{2} m^{3}+a^{2} c b h m e+a^{2} m^{2} e^{2} f+a c^{2} f^{2} m^{2}+a c f m h b^{2}+a c d{ }^{2} g m^{2}+a h^{2} b^{4}+3 a m^{2} d f b g+c m d^{2} h b^{2} \\
+m^{2} d^{2} e f b+m^{2} f^{3} b^{2}
\end{array}\right) \\
& e_{1}=-\frac{-\left(2 a^{2} c f g m^{2}+a^{2} d e m^{2} g+2 a^{2} b^{2} g m h+a c^{2} b h m d+a c m^{2} d e f+2 a m^{2} e f^{2} b+c m^{2} d f^{2} b+d^{3} b g m^{2}+2 m d f b^{3} h\right)}{b m\left(\left(m a c d e+m d c f b+2 m a e f b+a^{2} g m c+h b^{3} d\right)-\left(m d^{2} b e+m a^{2} e^{2}+m f^{2} b^{2}+f m a c^{2}+a g m d b+h b^{2} a c\right)\right)}
\end{aligned}
$$

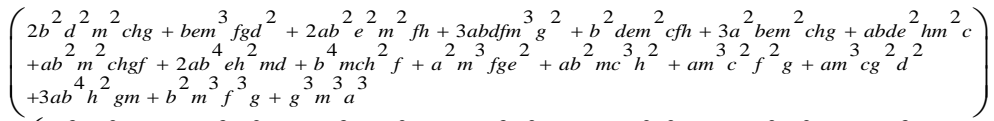

$$
\begin{aligned}
& e_{2}=-\frac{h}{m}, \quad f_{1}=-\frac{-\left(\begin{array}{l}
3 b^{3} d m^{2} h g f+b d m^{3} c f^{2} g+3 a b^{3} e m c h^{2}+2 a b e m^{3} f^{2} g+2 a b d m^{2} c^{2} g+a b e m m^{2} f c h+a d e m^{3} c f g \\
+a b^{2} d e h m^{2} g+b^{3} d m c^{2} h^{2}+b^{3} e m^{2} f^{2} h+b^{2} d^{2} h m^{2} e^{2}+2 a^{2} m^{3} c f g+a^{2} d e m^{3} g^{2}+3 a^{2} b^{2} g^{2} m^{2} h \\
+b g^{2} m^{3}+d^{3} b
\end{array}\right)}{b m\left(\begin{array}{l}
\left.\left(\begin{array}{l}
g^{2} m^{2} a^{3}+a^{2} c b h m e+a^{2} m^{2} e^{2} f+a c^{2} f^{2} m^{2}+a c f m h b^{2}+a c d \\
+c m d^{2} h b^{2}+m^{2} d^{2} e f b+m^{2} f^{3} b^{2}+a h^{2} b^{4}+3 a m^{2} d f b g
\end{array}\right)\right) \\
-\left(\begin{array}{l}
2 a^{2} c f m^{2} g+a^{2} d e m^{2} g+2 a^{2} g m h b^{2}+a c^{2} b h m d+a c m^{2} d e f+2 a m^{2} e f b+c m^{2} d f^{2} b \\
+d^{3} b g m^{2}+2 m d f b
\end{array}\right)
\end{array}\right)}
\end{aligned}
$$

Syarat kestabilan Routh Hurwitz terpenuhi karena semua koefisien karakteristik bernilai negatif dan tidak terdapat perubahan tanda dari semua elemen-elemen dari kolom pertama tabel Routh Hurwitz karena mempunyai tanda yang sama. Disimpulkan bahwa titik kritis $T_{1}$ bersifat stabil.

\subsection{Simulasi}

Dalam penelitian ini dilakukan simulasi model yang bertujuan untuk mengilustrasikan penyebaran penyakit antraks. Simulasi dilakukan dengan bantuan software matematika Maple 13 dengan memberikan nilai awal dan nilai parameter pada model. Nilai-nilai yang digunakan dalam penelitian ini dinyatakan dalam Tabel 2 dan Tabel 3.

Tabel 2 : Nilai Parameter

\begin{tabular}{|c|c|c|c|}
\hline No & Parameter & Nilai & Sumber \\
\hline 1 & $X$ & 0.04444444 & $\frac{1}{\text { Life Time Bakteri }}$ x Jum \\
\hline 2 & $Y$ & 0.0833333 & $\frac{1}{\text { Life Time Hewan }}$ x Jum \\
\hline
\end{tabular}




\begin{tabular}{|c|c|c|c|}
\hline 3 & $Z$ & 0.0105556 & $\frac{1}{\text { Life Time Manusia }}$ xJu \\
\hline 4 & $\alpha$ & 0.5 & Diasumsikan \\
\hline 5 & $\beta$ & 0.1428571 & Diasumsikan \\
\hline 6 & $\varepsilon$ & 0.0714286 & Diasumsikan \\
\hline 7 & $\gamma$ & 0.1111111 & Diasumsikan \\
\hline 8 & $\delta$ & 0.0333333 & Diasumsikan \\
\hline 9 & $\sigma$ & 0.0333333 & Diasumsikan \\
\hline 10 & $\mu_{1}$ & 0.0001389 & $\frac{\text { Life Time Hewan }}{1}$ \\
\hline 11 & $\mu_{2}$ & 0.0000427 & $\frac{\text { Life Time Manusia }}{2}$ \\
\hline 12 & $P_{1}$ & 0.2941176 & Diasumsikan \\
\hline 13 & $P_{2}$ & 0.3333333 & Diasumsikan \\
\hline 14 & $k$ & 10000 & Diasumsikan \\
\hline
\end{tabular}

Tabel 3 : Nilai Awal

\begin{tabular}{|c|c|c|c|}
\hline NO & Variabel & Nilai & Sumber \\
\hline 1 & $B$ & 8000 & Adji dan Natalia \\
\hline 2 & $S_{h}$ & 600 & SKRIPSI, Rahmawati \\
\hline 3 & $I_{h}$ & 238 & Yakin. E. A \\
\hline 4 & $R_{h}$ & 168 & Yakin. E. A \\
\hline 5 & $V$ & 230 & Yakin. E. A \\
\hline 6 & $S_{m}$ & 247 & SKRIPSI, Rahmawati \\
\hline 7 & $I_{m}$ & 9 & Fahdhienie F, dkk \\
\hline
\end{tabular}

Simulasi kondisi bebas penyakit antraks pada populasi hewan dengan pemberian vaksinasi diilustrasikan pada Gambar 2 untuk nilai awal bakteri Bacillus Anthracis (B) sebanyak 8000 bakteri, hewan rentan (Sh) sebanyak 600 ekor, tidak ada hewan terinfeksi (Ih), tidak ada hewan sembuh (Rh), hewan yang divaksin (V) sebanyak 230 ekor, manusia rentan (Sm) sebanyak 247 orang, dan tidak ada manusia terinfeksi (Im). 


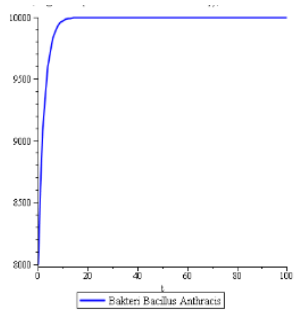

(2a)

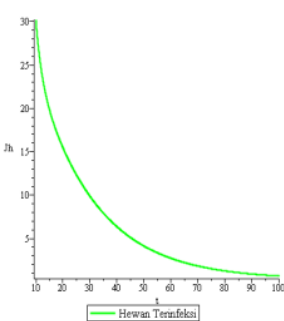

$\left(2 \mathrm{c}_{2}\right)$

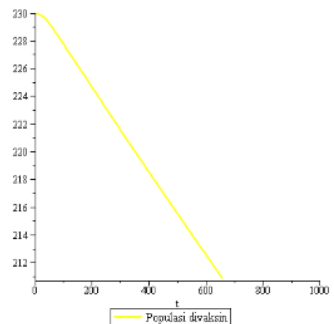

(2e)

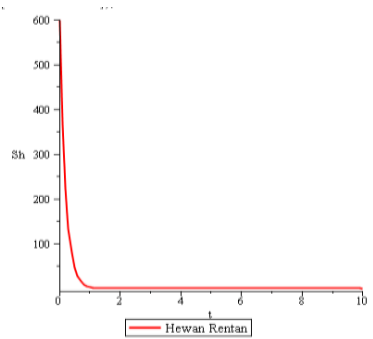

(2b)

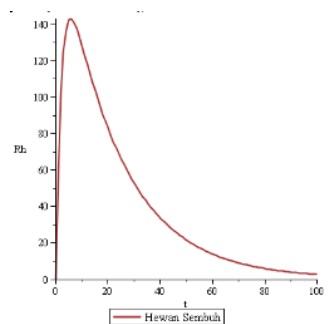

$\left(2 d_{1}\right)$

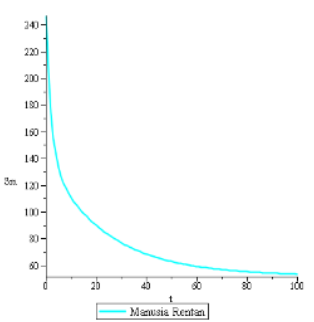

(2f)

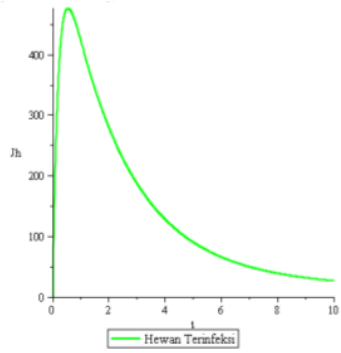

$\left(2 \mathrm{c}_{1}\right)$

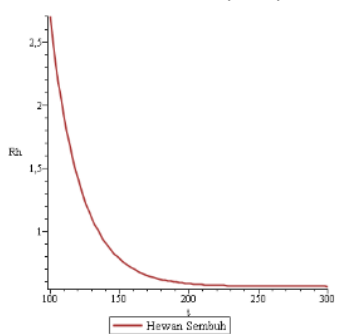

$\left(2 d_{2}\right)$

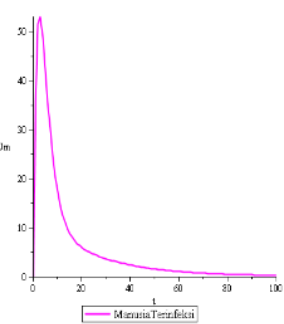

(2g)

Gambar 2 : Kurva Pertumbuhan Bakteri, Populasi Hewan, Populasi Manusia pada Kondisi Bebas Penyakit terhadap Waktu

Simulasi kondisi endemik antraks pada populasi hewan diberikan vaksinasi diilustrasikan pada Gambar 3 untuk nilai awal bakteri Bacillus Anthracis (B) sebanyak 8000 bakteri, hewan rentan (Sh) sebanyak 600 ekor, hewan terinfeksi (Ih) sebanyak 238 ekor, hewan sembuh (Rh) sebanyak 168 ekor, hewan yang divaksin (V) sebanyak 230 ekor, manusia rentan $(\mathrm{Sm})$ sebanyak 247 orang, dan manusia terinfeksi (Im) sebanyak 9 orang. 


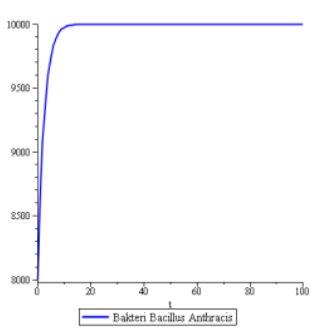

(3a)

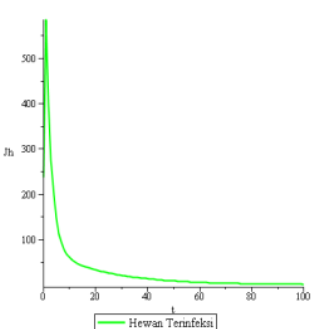

(3c)

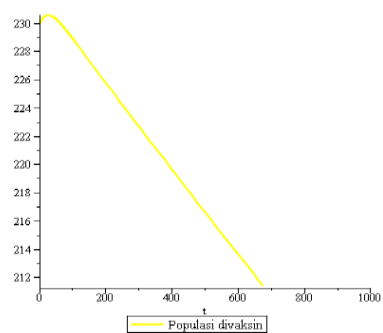

$(3 e)$

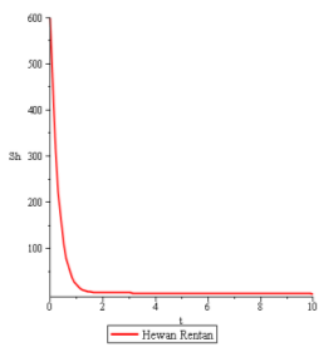

$\left(3 b_{1}\right)$

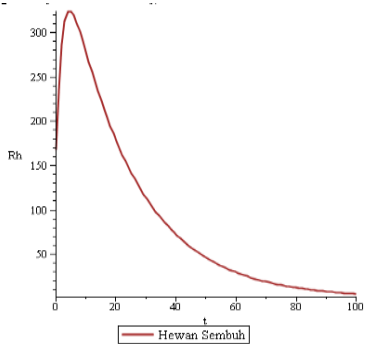

$\left(3 d_{1}\right)$

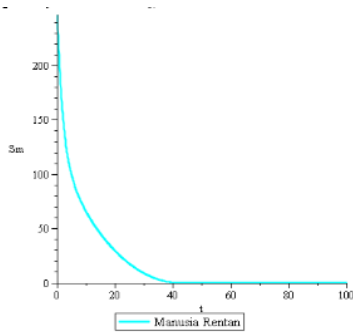

(3f)

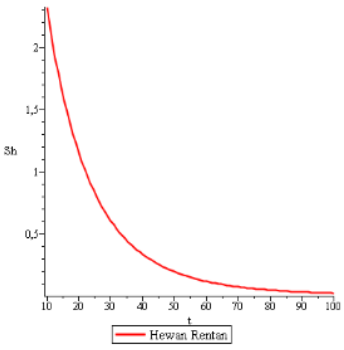

$\left(3 b_{2}\right)$

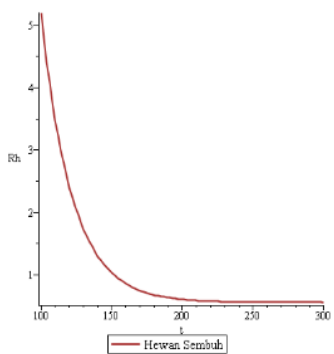

$\left(3 d_{2}\right)$

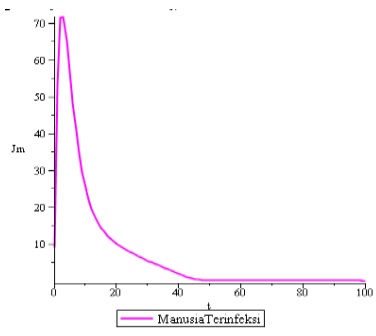

$(3 g)$

Gambar 3 : Kurva Pertumbuhan Bakteri, Populasi Hewan, Populasi Manusia pada Kondisi Endemik terhadap Waktu

\subsection{Pembahasan}

Gambar 2a dan 3a menunjukkan bahwa dinamika pertumbuhan bakteri Bacillus Anthracis pada kondisi bebas penyakit dan kondisi endemik tidak menunjukkan perbedaan pertumbuhan bakteri, keduanya mengikuti model logistik.

Perbandingan populasi hewan rentan, hewan terinfeksi, hewan sembuh, hewan divaksin, manusia rentan, dan manusia terinfeksi untuk kondisi bebas penyakit dan endemik pada setiap kelompok populasi digambarkan dalam Tabel 4.4 -4. 9. 
Tabel 4 : Perbandingan Populasi Hewan Rentan

\begin{tabular}{|c|c|c|c|c|}
\hline Kondisi & Keadaan Awal & Dalam 1 hari & Dalam 11 hari & Dalam 22 hari \\
\hline Bebas Penyakit & 600 & 4 & 0 & 0 \\
\hline Endemik & 600 & 9 & 2 & 0 \\
\hline
\end{tabular}

Tabel 5 : Perbandingan Populasi Hewan Terinfeksi

\begin{tabular}{|c|c|c|c|c|}
\hline Kondisi & Keadaan Awal & Dalam 0.5 hari & Dalam 52 hari & Dalam 100 hari \\
\hline Bebas Penyakit & 0 & 475 & 3 & 0 \\
\hline Endemik & 238 & 584 & 8 & 2 \\
\hline
\end{tabular}

Tabel 6 : Perbandingan Populasi Hewan Sembuh

\begin{tabular}{|c|c|c|c|c|}
\hline Kondisi & Keadaan Awal & Dalam 4 hari & Dalam 53 hari & Dalam 135 hari \\
\hline Bebas Penyakit & 0 & 142 & 18 & 0 \\
\hline Endemik & 168 & 323 & 38 & 1 \\
\hline
\end{tabular}

Tabel 7 : Perbandingan Populasi Hewan diVaksin

\begin{tabular}{|c|c|c|c|}
\hline Kondisi & Keadaan Awal & Dalam 25 hari & Dalam 651 hari \\
\hline Bebas Penyakit & 230 & 229 & 211 \\
\hline Endemik & 230 & 0.6 & 212 \\
\hline
\end{tabular}

Tabel 8 : Perbandingan Populasi Manusia Rentan

\begin{tabular}{|c|c|c|c|}
\hline Kondisi & Keadaan Awal & Dalam 31 hari & Dalam 80 hari \\
\hline Bebas Penyakit & 247 & 75 & 55 \\
\hline Endemik & 247 & 7 & 1 \\
\hline
\end{tabular}

Tabel 9 : Perbandingan Populasi Manusia Terinfeksi

\begin{tabular}{|c|c|c|c|c|}
\hline Kondisi & Keadaan Awal & Dalam 2 hari & Dalam 31 hari & Dalam 60 hari \\
\hline Bebas Penyakit & 0 & 52 & 3 & 0 \\
\hline Endemik & 9 & 71 & 5 & 0 \\
\hline
\end{tabular}

Dari Tabel 4 - 9 dapat diinterpretasikan bahwa dalam waktu yang sama kedua kondisi bebas penyakit dan kondisi endemik menunjukkan perbedaan banyaknya anggota sub populasi hewan terinfeksi dan populasi manusia terinfeksi yang tidak signifikan dan kedua kondisi tersebut menunjukkan keberhasilan vaksinasi khususnya dalam mengendalikan kondisi endemik sehingga populasi hewan terinfeksi dan manusia terinfeksi mengalami penurunan drastis (Gambar 2g dan Gambar 3g). 


\section{KESIMPULAN}

Berdasarkan penelitian yang dilakukan, maka dapat di simpulkan bahwa :

1. Model matematika untuk kestabilan penyebaran penyakit antraks dibangun dalam suatu sistem persamaan diferensial tak linier yang terdiri dari 7 persamaan, yakni:

$$
\begin{aligned}
& \frac{d B}{d t}=X B\left(1-\frac{B}{k}\right) \\
& \frac{d S_{h}}{d t}=Y-\frac{\alpha S_{h} B}{N_{h}}+\varepsilon R_{h}-Y \delta\left(S_{h}+\varepsilon R_{h}\right)-\mu_{1} S_{h} \\
& \frac{d I_{h}}{d t}=\frac{\alpha S_{h} B}{N_{h}}-\beta I_{h}-\mu_{1} I_{h}-P_{1} I_{h} \\
& \frac{d R_{h}}{d t}=\beta I_{h}-\varepsilon R_{h}-\sigma R_{h}-\mu_{1} R_{h} \\
& \frac{d V}{d t}=Y \delta\left(S_{h}+\varepsilon R_{h}\right)+\sigma R_{h}-\mu_{1} V \\
& \frac{d I_{m}}{d t}=\frac{\gamma I_{h} S_{m}}{N_{m}}-\mu_{2} I_{m}-P_{2} I_{m} \\
& \frac{\gamma t}{I_{h} S_{m}}-\mu_{2} S_{m} \\
& N_{m}
\end{aligned}
$$

2. Model penyebaran penyakit antraks memiliki titik kritis bebas penyakit $T_{0}=\left(0,0,0,0 \frac{Y}{Y \delta+\mu_{1}}, \frac{Y^{2} \delta}{\mu_{1}\left(Y \delta+\mu_{1}\right)}, \frac{Z}{\mu_{2}}\right)$ yang tidak stabil. Hal ini menunjukkan bahwa kondisi bebas penyakit tidak bersifat tetap. Adapun titik kritis endemik $T_{1}=\left(B, S_{h}, I_{h}, R_{h}, V, S_{m}, I_{m}\right)$ dimana

$$
\begin{aligned}
& B=k \\
& S_{h}=\frac{Y N_{h}\left(\beta+\mu_{1}+P_{1}\right)\left(\varepsilon+\sigma+\mu_{1}\right)}{\left(N_{h}\left(Y \delta+\mu_{1}\right)\left(\beta+\mu_{1}+P_{1}\right)\left(\varepsilon+\sigma+\mu_{1}\right)+k\left(\left(\beta+\mu_{1}+P_{1}\right) \mu_{1}\right.\right.} \\
& \left.\left.+\left(\beta Y \delta+\mu_{1}+P_{1}\right) \varepsilon+\left(\beta+\mu_{1}+P_{1}\right) \sigma\right) \alpha\right) \\
& I_{h}=\frac{Y \alpha k\left(\varepsilon+\sigma+\mu_{1}\right)}{\left(N_{h}\left(Y \delta+\mu_{1}\right)\left(\beta+\mu_{1}+P_{1}\right)\left(\varepsilon+\sigma+\mu_{1}\right)+k\left(\left(\beta+\mu_{1}+P_{1}\right) \mu_{1}\right.\right.} \\
& \left.\left.+\left(\beta Y \delta+\mu_{1}+P_{1}\right) \varepsilon+\left(\beta+\mu_{1}+P_{1}\right) \sigma\right) \alpha\right) \\
& R_{h}=\frac{Y \beta \alpha k}{\left(N_{h}\left(Y \delta+\mu_{1}\right)\left(\beta+\mu_{1}+P_{1}\right)\left(\varepsilon+\sigma+\mu_{1}\right)+k\left(\left(\beta+\mu_{1}+P_{1}\right) \mu_{1}\right.\right.} \\
& \left.\left.+\left(\beta Y \delta+\mu_{1}+P_{1}\right) \varepsilon+\left(\beta+\mu_{1}+P_{1}\right) \sigma\right) \alpha\right)
\end{aligned}
$$




$$
\begin{aligned}
& V=\frac{Z\left(\begin{array}{l}
N_{m} N_{h}\left(Y \delta+\mu_{1}\right)\left(\beta+\mu_{1}+P_{1}\right)\left(\varepsilon+\sigma+\mu_{1}\right)+k\left(\left(\beta+\mu_{1}+P_{1}\right) \mu_{1}\right. \\
\left.+\left(\beta Y \delta+\mu_{1}+P_{1}\right) \varepsilon+\left(\beta+\mu_{1}+P_{1}\right) \sigma\right) \alpha N_{m}
\end{array}\right)}{N_{m} N_{h}\left(Y \delta+\mu_{1}\right)\left(\beta+\mu_{1}+P_{1}\right)\left(\varepsilon+\sigma+\mu_{1}\right) \mu_{2}+k\left(\mu _ { 2 } \left(\left(\beta+\mu_{1}+P_{1}\right) \mu_{1}\right.\right.} \\
& \left.\left.+\left(\beta Y \delta+\mu_{1}+P_{1}\right) \varepsilon+\left(\beta+\mu_{1}+P_{1}\right) \sigma\right) N_{m}+\gamma Y\left(\varepsilon+\sigma+\mu_{1}\right)\right) \alpha \\
& S_{m}=\frac{\gamma Y \alpha k\left(\varepsilon+\sigma+\mu_{1}\right) Z}{\left(\mu_{2}+P_{2}\right)\left(\begin{array}{l}
N_{m} N_{h}\left(Y \delta+\mu_{1}\right)\left(\beta+\mu_{1}+P_{1}\right)\left(\varepsilon+\sigma+\mu_{1}\right) \mu_{2} \\
+k\left(\mu _ { 2 } \left(\left(\beta+\mu_{1}+P_{1}\right) \mu_{1}+\left(\beta Y \delta+\mu_{1}+P_{1}\right) \varepsilon\right.\right. \\
\left.\left.+\left(\beta+\mu_{1}+P_{1}\right) \sigma\right) N_{m}+\gamma Y\left(\varepsilon+\sigma+\mu_{1}\right)\right) \alpha
\end{array}\right)} \\
& I_{m}=\frac{Y\left(Y \delta \varepsilon N_{h}\left(\beta+\mu_{1}+P_{1}\right)\left(\varepsilon+\sigma+\mu_{1}\right)+k \alpha(Y \delta \varepsilon+\sigma) \beta\right)}{\mu_{1}\left(\begin{array}{l}
N_{h}\left(Y \delta+\mu_{1}\right)\left(\beta+\mu_{1}+P_{1}\right)\left(\varepsilon+\sigma+\mu_{1}\right)+k\left(\left(\beta+\mu_{1}+P_{1}\right) \mu_{1}\right. \\
\left.+\left(\beta Y \delta+\mu_{1}+P_{1}\right) \varepsilon+\left(\beta+\mu_{1}+P_{1}\right) \sigma\right) \alpha
\end{array}\right)}
\end{aligned}
$$

yang stabil menunjukkan bahwa penyakit antraks pada populasi hewan dengan pemberian vaksinasi pada hewan akan menetap.

3. Hasil simulasi menunjukkan bahwa dalam waktu yang sama kedua kondisi bebas penyakit dan kondisi endemik memberikan perbedaan banyaknya anggota sub populasi hewan terinfeksi dan populasi manusia terinfeksi yang tidak signifikan dan menunjukkan keberhasilan vaksinasi khususnya dalam mengendalikan kondisi endemik sehingga populasi hewan terinfeksi dan manusia terinfeksi mengalami penurunan drastis.

\section{DAFTAR PUSTAKA}

[1]. Adji, R.S., dan Natalia L, Antraks, Pengendalian Penyakit Antraks: Diagnosis, Vaksinasi dan Investigasi, Balai Besar Veteriner, 2006, Bogor., 198; 202, 16(4).

[2]. Astiti, L.G.S., Manajemen Pencegahan dan Pengendalian Penyakit pada Ternak Sapi, Balai Pengkajian Teknologi Pertanian, 2010, Nusa Tenggara Barat, 5.

[3]. Hardjoutomo. S., dan Poerwadikarta. M.B., Kajian Retrospektif Antraks di Daerah Endemik Menggunakan Uji Enzyme-Linked Immunosorbent Assay (ELISA), Balai Penelitian Veteriner, 1996, Bogor, 127, 2 (2).

[4]. H.S, Gigieh. S, Pengaruh Pendididkan Kesehatan Tentang Pencegahan Penyakt Antraks Terhadap Pengetahuan dan Sikap Peternak Sapi di Desa Brojol Miri Sragen, Skrpsi S1 Program Studi Keperawatan Fakultas IImu Kesehatan, 2012, Surakarta: Universitas Muhammadiyah Surakarta, 5.

[5]. Yakin, E.A., Vaksinasi Anthrax di Indonesia, Widyatama, 2010, Bandung, 2-3, 19(1). 